Original article

\title{
Effect of snakehead fish extract on kidney function in patients undergoing radiotherapy
}

\author{
Purwoko, Muhammad Husni Thamrin, Rio Rusman \\ Sebelas Maret University / Dr Moewardi General Hospital, Surakarta, Indonesia \\ Received 24 September 2020, Revised 9 July 2021, Accepted 27 October 2021
}

C 2020, Russian Open Medical Journal

\begin{abstract}
Background - Most malignancy patients that undergo radiotherapy with or without chemotherapy, especially those with malignancy of the pelvic region, are accompanied by hypoalbuminemia and kidney injury. Human albumin has been shown to have nephroprotective effects. Snakehead fish extract, a consumable source of albumin, can be an effective and cheap alternative to reduce the risk of kidney injury in malignancy patients.

Objective - Analyze the effect of snakehead fish extract on urea, creatinine, and albumin serum levels in radiotherapy patients.

Material and Methods - This study was conducted on patients undergoing radiotherapy. They were divided into two groups, each consisting of 15 patients; the control group was given a placebo and the experimental group was given snakehead fish extract. Albumin, urea, and creatinine serum levels were determined respectively by the bromocresol green method, urease method, and jaffe method, both before and after treatment. All data were analyzed using SPSS 22.0.

Results - The serum albumin level decreased in both groups. While it dropped further in the treatment group than in the control group, the difference was not significant. Urea and creatinine serum levels decreased in the experimental group and increased in the control group. Once more, however, this difference was not statistically significant.

Conclusion - The administration of snakehead fish extract had no significant effect on albumin, urea, or creatinine serum levels in patients undergoing radiotherapy.
\end{abstract}

Keywords: albumin, creatinine, radiotherapy, snakehead fish extract, urea.

Cite as Purwoko, Thamrin MH, Rusman R. Effect of snakehead fish extract on kidney function in patients undergoing radiotherapy. Russian Open Medical Journal 2021; 10: e0420.

Correspondence to Purwoko. Address: Department of Anesthesiology and Intensive Therapy, Faculty of Medicine, Sebelas Maret University / Dr Moewardi General Hospital, Jl. Kolonel Sutarto St. No. 132, Surakarta 50126, Central Java, Indonesia. Phone: (+62) 271 639262. Email: purwokoanest@gmail.com.

\section{Introduction}

Hypoalbuminemia is indicated by an albumin serum level below $3.5 \mathrm{~g} / \mathrm{dl}$; clinically significant hypoalbuminemia is generally considered to be under $2.5 \mathrm{~g} / \mathrm{dl}$ [1]. Most patients with terminal cancer also have hypoalbuminemia. This condition may be the result of a drop in the production (rare) of albumin, increased albumin catabolism, a shorter half-life of albumin, or the loss of albumin through the kidneys, gastrointestinal (GI) tract, skin, or extravascular space [2]. Hypoalbuminemia can also stem from radiotherapy [3]. To prevent this, patients are usually advised to adopt a high protein high-calorie diet, with white egg, modified dried skimmed milk and coconut if needed.

Radiotherapy with or without chemotherapy for pelvic malignancy, which includes gastrointestinal malignancy, gynecologic malignancy, lymphoma, and upper body sarcoma, can result in renal damage, especially radiation nephropathy, through total body irradiation [4].

Albumin is known to be a nephroprotective agent. Albumin supplementation does not only help to reduce mortality in septic shock patients but it also more reliably achieves hemodynamic stabilization. The need for vasopressor therapy is reduced in patients receiving albumin. Fluid retention is a common complication in patients who require treatment in intensive care units and can cause problems once a patient is pulled from the ventilator. Some studies show that treatment with human albumin and a diuretic is more effective at treating fluid retention compared with treatment with a diuretic alone [5]

Albumin capsule supplements are known as inexpensive yet effective in increasing albumin serum levels. A common way to supplement albumin orally is through consumption of the snakehead fish, whether it is cooked into dishes or processed as an extract [6].

Utomo showed that snakehead fish extract capsules increase the level of albumin serum in hypoalbuminemia patients and decrease the length of hospital stay and, in turn, financial burden. However, one study indicated that supplementation with this extract in hypoalbuminemia patients in National General Hospital Dr. Cipto Mangunkusumo (RSCM) results in a decrease in creatinine clearance [7].

This study aims to analyze the effect of snakehead fish extract on albumin, urea, and creatinine serum levels in patients undergoing radiotherapy. 
Table 1. Subject Characteristics

\begin{tabular}{lccc}
\hline Characteristics & \multicolumn{2}{c}{ Group } & $p$ \\
\hline Age & $55.40 \pm 9.51$ & $56.87 \pm 7.69$ & 0.646 \\
Sex & & & 1.000 \\
M & $1(6.7 \%)$ & $1(6.7 \%)$ & \\
F & $14(93.3 \%)$ & $14(93.3 \%)$ & \\
BMI & $22.78 \pm 3.64$ & $23.21 \pm 4.04$ & 0.760 \\
Type of tumor & & & 0.712 \\
Bladder cancer & $0(0.0 \%)$ & $1(6.7 \%)$ & \\
Endometrial cancer & $1(6.7 \%)$ & $1(6.7 \%)$ & \\
Rectal cancer & $2(13.3 \%)$ & $1(6.7 \%)$ & \\
Cervical cancer & $12(80.0 \%)$ & $12(80.0 \%)$ & \\
Chemotherapy session & & & 0.472 \\
Positive & $6(40.0 \%)$ & $3(20.0 \%)$ & \\
Negative & $9(60.0 \%)$ & $12(80.0 \%)$ & \multirow{2}{*}{0.025} \\
Adverse effect & & $3(20.0 \%)$ & \\
Positive & $9(60.0 \%)$ & $12(80.0 \%)$ & \\
Negative & $6(40.0 \%)$ & & \\
\hline
\end{tabular}

Table 2. Albumin Levels of $\mathrm{K} 1$ and $\mathrm{K} 2$

\begin{tabular}{|c|c|c|c|}
\hline \multirow{2}{*}{ Albumin } & \multicolumn{2}{|c|}{ Group } & \multirow{2}{*}{$p$-value } \\
\hline & $\mathrm{K} 1$ & $\mathrm{~K} 2$ & \\
\hline Pre-test & $3.60 \pm 0.43$ & $3.76 \pm 0.42$ & 0.312 \\
\hline Post-test & $3.55 \pm 0.42$ & $3.74 \pm 0.40$ & 0.223 \\
\hline p-value (pair) & 0.605 & $0.820^{2}$ & \\
\hline Difference & $-0.05 \pm 0.34$ & $-0.02 \pm 0.33$ & 0.831 \\
\hline
\end{tabular}

Table 3. Serum Urea Levels of K1 and K2

\begin{tabular}{lccc}
\hline \multirow{2}{*}{ Serum Urea Level } & \multicolumn{2}{c}{ Group } & K2 \\
& K1 & p-value \\
\hline Pre-test & $22.73 \pm 5.80$ & $33.33 \pm 27.40$ & 0.630 \\
Post-test & $22.47 \pm 8.26$ & $42.27 \pm 58.78$ & 0.359 \\
p-value & 0.889 & 0.552 & \\
Difference $^{-}$ & $-0.27 \pm 8.38$ & $8.93 \pm 43.19$ & 0.950 \\
\hline
\end{tabular}

Table 4. Serum Creatinine Levels of K1 and K2

\begin{tabular}{lccc}
\multicolumn{4}{c}{ Table 4. Serum Creatinine Levels of K1 and K2 } \\
\hline \multirow{2}{*}{ Serum Creatinine Level } & K1 & K2 & p-value \\
\hline Pre-test & $0.78 \pm 0.25$ & $0.97 \pm 0.65$ & 0.752 \\
Post-test $_{\text {p-value }_{\text {(pair) }}}$ & $0.71 \pm 0.16$ & $1.03 \pm 0.86$ & 0.524 \\
Difference & 0.210 & 0.810 & \\
\hline
\end{tabular}

\section{Material and Methods \\ Research design}

This study was an experimental quantitative research with pretest-posttest control group design. This design comprised of two group, experimental group and control group. Experimental group was given snakehead fish extract, whereas control group given placebo. For sampling, we used accidental sampling, which means anyone accidentally meet researcher can be taken as sample, if we thought he meet the criteria. This study focused on patients undergoing radiotherapy at Dr. Moewardi General Hospital since July 2019. We used the standard rule of thumb to determine our sample size. Our sample was made up of 30 patients selected based on several inclusion and exclusion criteria. The inclusion criteria were as follows: adult man or woman; aged 18-65; undergoing radiotherapy; willing to participate in this study and follow our procedures. The exclusion criteria were as follows: allergic to snakehead fish; suffering from chronic renal or liver diseases. Moreover, there were also dropout criteria: recalls informed consent; fails to follow our procedures. This study has been approved by the Health Research Ethics Committee at Dr. Moewardi General Hospital with letter number 762/VI/HREC/2019 and has been performed in accordance with the ethical standards as laid down in the 1964 Declaration of Helsinki and its later amendments or comparable ethical standards.

\section{Sample analysis}

Subjects who had undergone 10 radiotherapy sessions were divided into two groups consisting of 15 subjects: treatment group (K1) and control group (K2). The albumin, urea, and creatinine serum levels were measured before subjects were provided with snakehead fish extract or a placebo. K1 was given two capsules of snakehead fish extract three times a day for 14 consecutive days. Over the same period, K2 was given two placebo capsules three times a day. The capsules given to $\mathrm{K} 1$ contained $500 \mathrm{mg}$ of albumin extracted from snakehead fish. After 14 days and 20 sessions of radiotherapy, we measured albumin, urea, and creatinine serum levels using the bromocresol green method, urease method, and Jaffe method, respectively.

\section{Statistical analysis}

The data we obtained were analyzed using SPSS 22.0. The hypothetical comparative statistical testing method (KolmogorovSmirnov test and Shapiro-Wilk test) used to analyze albumin, urea, and creatinine serum levels before and after treatment was the paired t-test; the method used to analyze the differences between albumin, urea, and creatinine serum levels in K1 and K2 was the independent t-test. Statistical significance was indicated if $p$ value $<0.05$

\section{Results}

The average age of subjects in $\mathrm{K} 1$ was $55.40 \pm 9.51$; in $\mathrm{K} 2$, it was $56.87 \pm 7.69$. Most subjects in both groups were female (14; 93.3\%). Body mass index (BMI) in both groups was within the normal limit. Most patients in both groups were diagnosed with cervix carcinoma (12 patients, $80.0 \%$ ). Most subjects in both groups did not undergo chemotherapy. Gastrointestinal adverse effects in K1 were mostly positive (12 patients, $80.0 \%$ ). Subject characteristics are shown in Table 1.

The average reduction of serum albumin levels in $\mathrm{K} 1$ from before treatment to after treatment was $-0.05 \pm 0.34$; the reduction was not statistically significant $(p=0.605)$. The average reduction of serum albumin levels in $\mathrm{K} 2$ from before treatment to after treatment was $-0.02 \pm 0.33$; once more, the reduction was not statistically significant $(p=0.820)$. Neither the independent t-tests of both $\mathrm{K} 1$ and $\mathrm{K} 2$ on the pre-test and post-test levels nor the difference in albumin level reduction between the two groups were found to be statistically significant $(p=0.312, p=0.223$, $\mathrm{p}=0.831$ ) (Table 2).

The average reduction of serum urea levels in $\mathrm{K} 1$ from before treatment to after treatment was $-0.27 \pm 8.38$ but was not statistically significant $(p=0.605)$. Average levels rose in $K 2$ from before to after treatment, the average being $8.93 \pm 43.19$. Neither the independent t-tests of both $\mathrm{K} 1$ and $\mathrm{K} 2$ on the pre-test and post-test levels nor the difference in serum urea level reduction between the two groups were found to be statistically significant $(p=0.630, p=0.359, p=0.950)$ (Table 3$)$.

There was a reduction in serum creatinine levels in $\mathrm{K} 1$ with an average of $-0.07 \pm 0.18$ after 14 days of snakehead fish extract 
treatment, though it was not statistically significant $(p=0.210)$. Additionally, there was no statistically significant difference in serum creatinine levels between pre- and post-treatment measures in $\mathrm{K} 2(\mathrm{p}=0.810 ; 0.06 \pm 0.29)$. Neither the independent $t$ tests of both $\mathrm{K} 1$ and $\mathrm{K} 2$ on the pre-test and post-test levels nor the difference in serum creatinine level reduction between the two groups were found to be statistically significant (Table 4).

\section{Discussion}

The results of this study are not consistent with several researches, such as Chairudin, Restiana, and Kasim et al., whom studies showed that orally supplementation of albumin was effective in improving the level of albumin [7-9]. Still, the study of Salma in PLHIV showed that the supplementation of two capsules of snakehead fish extract three times a day significantly increased the level of albumin at $0.6 \mathrm{~g} / \mathrm{dl}[8]$.

These inconsistent results is caused by the cancer status and radiotherapy session received by the subjects. There is an increasing uptake of albumin by tumor cells and the function of total protein, especially albumin, as an antioxidant in cancer patients, plays a role [10]. This could be due to its high content of thiol groups which have a chain breaking effect in the termination of the chain reaction of lipid peroxidation [11]. Another reason is the loss of serum protein caused by the increased capillary permeability as the adverse effect of gamma radiation. Radiotherapy, especially gamma radiation, modified the structure of albumin [12].

The study of Frenette et al. is consistent with the results of this study. They investigated the effect of albumin to the risk of acute kidney injury (AKI) in patients underwent cardiac surgery by propensity score analysis. Frenette et al. used crystalloid and colloid as fluid infusion during 36 hours after surgery. After 96 hours after surgery, the incident of AKI was $5.3 \%$ based on RIFLE risk criteria. In this analysis, albumin was linked with increased risk of AKI [13].

Some studies, such as CRYCO study group conducted observational research on 1013 patients suffering from shock. The infusion of hyperoncotic albumin was linked with the increased risk of renal damage, as for five times more susceptible. Albumin was happened to increased serum creatinine level and risk of dialysis [13].

The results of this study may be caused by gastrointestinal effect of radiotherapy such as nausea, vomitus, diarrhea, decreased of appetite. This adverse effect was mostly happened in K1. The dose of snakehead fish extract was not sufficient to make any effect for patients receiving radiotherapy session who had gastrointestinal adverse effect. The limitations of this study are the existence of chemotherapy side effects (such as nausea, diarrhea and anorexia) in control group and the single-dose administration of snakehead fish extract. Future studies will be required to determine the multiple-doses administration of snakehead fish extract in the larger group samples.

\section{Conclusion}

The administration of snakehead fish extract had no significant effect on albumin, urea, or creatinine serum levels in patients undergoing radiotherapy sessions. Snakehead fish extract may need to be given in larger doses to patients experiencing adverse gastrointestinal effects. To properly assess the effect of snakehead fish extract on renal function, it is necessary to investigate patients with Acute Kidney Injury (AKI).

\section{Acknowledgments}

We sincerely thank to Rita Budianti (Department of Radiotherapy, Dr Moewardi General Hospital). This study was supported by a grant from Royal Medicalink Pharmalab Inc.

\section{Conflict of interest}

The authors declare no conflicts of interest.

\section{Authors' contributions}

Purwoko developed the concept and designed the study, along with data collection and analysis. Muhammad Husni Thamrin wrote the original draft and revised it. Rio Rusman wrote interpretation of data and approved the final version for publication.

\section{Ethical approva}

All procedures performed in studies involving human participants were in accordance with the ethical standards of the institutional and/or national research committee and with the 1964 Declaration of Helsinki and its later amendments or comparable ethical standards.

\section{References}

1. Moujaess E, Fakhoury M, Assi T, Elias H, Karak FE, Ghosh M, et al. The Therapeutic use of human albumin in cancer patients' management. Crit Rev Oncol Hemat 2017; 120: 203-209. https://doi.org/10.1016/j.critrevonc.2017.11.008.

2. Douglas RG, Shaw JH. Metabolic effects of cancer. Br J Surg 1990 77(3): 246-254. https://doi.org/10.1002/bjs.1800770305.

3. Nyarota KM, Zhou DT. Determination of protein in cancer patients at radiotherapy clinic, Zimbabwe. Saudi J Med Pharm Sci. 2017; 3(10) 1071-1076. https://doi.org/10.21276/sjmps.2017.3.10.10.

4. Baradaran-Ghahfarokhi M. Radiation-induced kidney injury. J Renal Inj Prev 2012; 1(2): 49-50. https://doi.org/10.12861/jrip.2012.17.

5. Wiedermann CJ, Joannidis M. Nephroprotective potential of human albumin infusion: a narrative review. Gastroenterol Res Pract 2015 2015: 912839. https://doi.org/10.1155/2015/912839.

6. Supriyatna. The Changes in Albumin Levelof Hypoalbuminemic Subjects UndergoingSurgery Receiving White Egg Supplementationin Dr. Kariadi Hospital Semarang. Med Hosp 2012; 1(2): 130-133. Indonesian. https://doi.org/10.36408/mhjcm.v1i2.59.

7. Chairuddin B. Effectiveness of administration of cork fish extract albumin capsules on the increase in blood albumin levels in severe preeclamptic patients post-caesarean section. Master Thesis. Surakarta, Indonesia: Department of Family Medicine, Sebelas Maret University. 2012; $47 \quad$ p. Indonesian. https://digilib.uns.ac.id/dokumen/detail/79113/Efektifitas-PemberianKapsul-Albumin-Ekstrak-Ikan-Gabus-terhadap-Kenaikan-KadarAlbumin-dalam-Darah-Pasien-Preeklampsia-Berat-Pasca-SeksioSesaria.

8. Restiana, Nurpudji A. Taslim, Agussalim Bukhari. The Influence Of Striped Snakehead Fish (Channa Striata) Extract On Albumin Level And Nutritious Status Of HIV/AIDS Patients With ARV Therapy. 2010.Makasar, Indonesia: Hasanuddin University. 2010: 148 http://pasca.unhas.ac.id/jurnal/files/5db462c0f32abe0c1eb16ec41c4e cf5e.pdf

9. Kasim VN, Pateda SM, Hadju V, Jafar M. Suplementasi ekstrak albumin ikan gabus terhadap status gizi dan imunitas pasien stroke [Supplementation of snakehead fish albumin extract on nutritional status and immunity of stroke patients]. Jurnal Gizi Klinik Indonesia 2017; 13(3): 91-98. Indonesian. https://doi.org/10.22146/ijcn.21964. 
10. Youssef HM, Salem HT. Oxidative stress parameters in patients with breast cancer before and after radiotherapy. Egypt J Rad Sci Applic 2019; 32(2): 177-185. https://doi.org/10.21608/ejrsa.2019.15164.1079.

11. Halliwell B. Albumin - an important extracellular antioxidant? Biochem Pharmacol 1988; 37(4): 569-571. https://doi.org/10.1016/00062952(88)90126-8.

12. Gaber MH. Effect of gamma irradiation on the molecular properties of bovine serum albumin. J Biosci Bioeng 2005; 100(2): 203-206. https://doi.org/10.1263/jbb.100.203.

13. Frenette AJ, Bouchard J, Bernier P, Charbonneau A, Nguyen LT, Rioux $J P$, et al. Albumin administration is associated with acute kidney injury in cardiac surgery: a propensity score analysis. Crit Care 2014; 18(6): 602. https://doi.org/10.1186/s13054-014-0602-1.

\section{Authors:}

Purwoko - Head of PPDS Anesthesiology and Intensive Therapy Program, Department of Anesthesiology and Intensive Therapy, Faculty of Medicine, Sebelas Maret University / Dr Moewardi General Hospital, Surakarta, Indonesia. https://orcid.org/0000-0001-6780-1687.

Muhammad Husni Thamrin - Functional Medical Staff, Department of Anesthesia and Intensive Therapy, Faculty of Medicine, Faculty of Medicine, Sebelas Maret University / Dr Moewardi General Hospital, Surakarta, Indonesia. https://orcid.org/0000-0001-9485-8873.

Rio Rusman - Resident, Department of Anesthesiology and Intensive Therapy, Faculty of Medicine, Sebelas Maret University, Surakarta, Indonesia. https://orcid.org/0000-0002-4792-8987. 